\title{
Correction of urodynamic disorders in women with genitourinary syndrome using a fractional $\mathrm{CO}_{2}$-laser
}

\author{
V.O. Beniuk, V.M. Goncharenko, M.S. Puchko, A.A. Momot, T.V. Kovaliuk, V.O. Polovynka
}

Bogomolets National Medical University, Kyiv

This article is devoted to the treatment of urodynamic disorders in women with the genitourinary syndrome by using a fractional $\mathrm{CO}_{2}$-laser. Nowdays, the development of genitourinary syndrome is an urgent problem among women of different ages. Genitourinary disorders are a complex of symptoms associated with the development of atrophic and dystrophic processes in the estrogenic tissues (the urethra, lower third of the uterus, pelvic floor ligaments and muscles). The objective: to determine the pathogenetic effectiveness of $\mathrm{CO}_{2}$ laser in the treatment of urodynamic disorders in premenopausal women with genitourinary syndrome.

Materials and methods. The study covered 130 female patients with symptoms of the genitourinary syndrome. The patients were divided into two groups depending on their treatment. The main group consisted of 56 women using $\mathrm{CO}_{2}$ laser therapy. The comparison group consisted of 74 women who were treated with local application of hormone. To assess the efficacy of treatment and the functional status of the lower urinary tract, a comprehensive pre-treatment and post-treatment urodynamic examination were performed.

Results. The average age of the patients in the examined groups was $47.2 \pm 2.5$ years. After the treatment, the urodynamic examination showed an increase of the maximal intraurethral pressure from $16.8 \pm 17.9$ to $26.7 \pm 21.2 \mathrm{~mm} \mathrm{Hg}$ in the main group (p<0.01). The urethral closure pressure increased from $15.3 \pm 13.2$ to $26.8 \pm 18.5 \mathrm{~mm} \mathrm{Hg}(\mathrm{p}<0.01)$. These changes were found upon examination of the functional length of the urethra, which increased from $2.0 \pm 0.3$ to $3.0 \pm 0.4 \mathrm{~cm}$, and thus reached normative values for healthy women. At the same time, the pre-treatment and post-treatment indicators did not statistically differ in comparison group.

Conclusions. The results of the study show that the MonaLisaTouch method of laser fractional ablation of vaginal and vulva epithelium is highly effective compared with local hormonal therapy and can be recommended as a monotherapy for urogenital disorders and pelvic floor dysfunction.

Key words: genitourinary syndrome, $\mathrm{CO}_{2}$-laser, estriol, urodynamic examination.

\section{Корекція уродинамічних порушень у жінок з генітоуринарним синдромом шляхом застосування фракційного $\mathrm{CO}_{2}$-лазера \\ В.О. Бенюк, В.М. Гончаренко, М.С. Пучко, А.А. Момот, Т.В. Ковалюк, В.О. Половинка}

Стаття присвячена корекції уродинамічних порушень у жінок з генітоуринарним синдромом шляхом застосування фракційного $\mathrm{CO}_{2}$-лазера. Сьогодні розвиток генітоуринарного синдрому є актуальною проблемою серед жінок різного віку. Генітоуринарні розлади - це комплекс симптомів, пов'язаних з розвитком атрофічних і дистрофічних процесів в естрогенозалежних тканинах (піхва, сечівник, сечовий міхур, нижня третина сечоводів, зв'язки і м'язи тазового дна).

Мета дослідження: визначення та патогенетичне обгрунтування ефективності використання СО $\mathrm{CO}_{2}$-лазера у лікуванні уродинамічних порушень у пацієнток у пременопаузальний період з генітоуринарним синдромом.

Матеріали та методи. Обстежено 130 пацієнток з симптомами генітоуринарного синдрому. Залежно від призначеної терапії їх розподілено на дві групи. До основної групи увійшли 56 жінок, яким запропоновано терапію із застосуванням $\mathrm{CO}_{2}$-лазера. До групи порівняння включено 74 жінки, яким призначали терапію з місцевим застосуванням естріолу.

3 метою оцінювання ефективності лікування та функціонального стану нижніх сечовидільних шляхів проводили комплексне уродинамічне дослідження до лікування та після нього.

Результати. Середній вік пацієнток обстежених груп становив 47,2 2,5 року. Після проведеного лікування за даними уродинамічного дослідження в основній групі відзначено збільшення максимального внутрішньоуретрального тиску

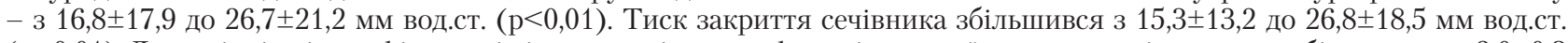
$(\mathrm{p}<0,01)$. Достовірні зміни зафіксовані під час дослідження функціональної довжини сечівника, яка збільшилась $32,0 \pm 0,3$

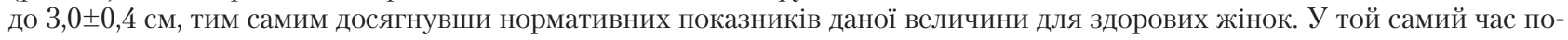
казники в групі порівняння до та після лікування статистично не відрізнялись.

Заключення. Результати дослідження свідчать, що метод лазерної фракційної абляції вагінального епітелію та вульви MonaLisaTouch є високоефективним порівняно з місцевою гормональною терапією і може бути рекомендований як монотерапія урогінекологічних розладів та дисфункції тазового дна.

Ключові слова: генітоуринарний синдром, СО2-лазер, естріол, уродинамічне дослідження.

\section{Коррекция уродинамических нарушений у женщин с генитоуринарным синдромом путем применения фракционного $\mathrm{CO}_{2}$-лазера В.А. Бенюк, В.Н. Гончаренко, М.С. Пучко, А.А. Момот, Т.В. Ковалюк, В.А. Половинка}

Статья посвящена коррекции уродинамических нарушений у женщин с генитоуринарным синдромом путем применения фракционного $\mathrm{CO}_{2}$-лазера. Сегодня развитие генитоуринарного синдрома является актуальной проблемой среди женщин всех возрастов. 


\section{н А до Помогу Л І К А Ю - П Р К тику}

Генитоуринарные расстройства - это комплекс симптомов, связанных с развитием атрофических и дистрофических процессов в эстрогензависимых тканях (влагалище, мочеиспускательный канал, мочевой пузырь, нижняя треть мочеточников, связки и мышцы тазового дна).

Цель исследования: определение и патогенетическое обоснование эффективности использования СО $\mathrm{C}_{2}$-лазера в лечении уродинамических нарушений у пациенток в пременопаузальный период с генитоуринарным синдромом.

материалы и методы. Обследовано 130 пациенток с симптомами генитоуринарного синдрома. В зависимости от назначенной терапии их распределено на две группы. В основную группу вошли 56 женщин, которым предложено терапию с применением $\mathrm{CO}_{2}$-лазера. В группу сравнения вошли 74 женщины, которым назначали терапию с местным применением эстриола. С целью оценки эффективности лечения и функционального состояния нижних мочевыводящих путей проводили комплексное уродинамическое исследование до лечения и после него.

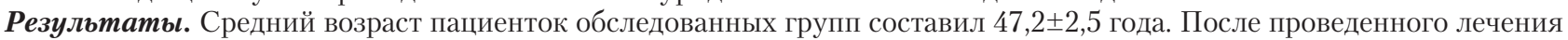
по данным уродинамического исследования в основной группе отмечено увеличение максимального внутриуретраль-

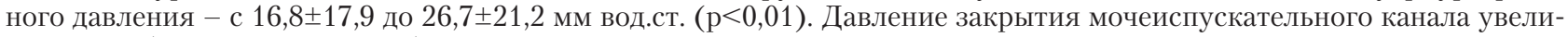

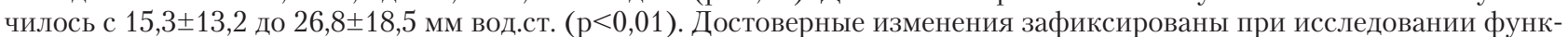

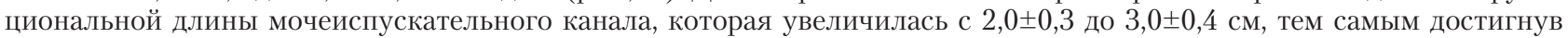
нормативных показателей данной величины для здоровых женщин. В то же время показатели в группе сравнения до и после лечения статистически не отличались.

Заключение. Результаты исследования показывают, что метод лазерной фракционной абляции вагинального эпителия и вульвы MonaLisaTouch является высокоэффективным по сравнению с местной гормональной терапией и может быть рекомендован в качестве монотерапии урогинекологических расстройств и дисфункции тазового дна.

Ключевые слова: генитоуринарный синдром, $\mathrm{CO}_{2}$-лазер, әстриол, уродинамическое исследование.

$\mathrm{T}$ heGenitourinarysyndrome(GS)isacomplexofsymptoms that manifest as a dysfunction in the genitourinary system in women after 45 years. The development of this pathology is primarily associated with a decrease in the content of estrogens and other important sex hormones. According to WHO data, the complex of GS manifestations includes changes in the external genitals, vagina, urethra and bladder, manifested by atrophic cystourethritis, genital prolapses, urinary incontinence, dyspareunia and vulvovaginal atrophy [1, 3, 5, 6, 21, 29, 32-34].

The clinical picture of atrophic cystourethritis (AC) is represented by cystalgia, frequent urination, nycturia and urinary incontinence $[7,8,28]$. The main common complaints of patients with vulvovaginal atrophy (VVA) and $\mathrm{AC}$ are itching, burning, dryness, vaginal discomfort, dyspareunia, bleeding from the vagina during or after sexual intercourse, pain and burning during the process of urination, frequent urination, nycturia, recurrent infections of the urogenital tract and urgent urges to urinate. As a rule, complaints are persistent and progress over the time [9, 11, 15, 17, 26, 30-32].

Along with GS, women of this ages often suffer from genital prolapse (GP), which is the result of the pelvic floor muscles and ligaments failure due to the lack or destruction of collagen fibers [9, 10]. Other possible factors for the GP occurrence include: pregnancy and childbirth, pathology of the uterine ligaments, chronic intra-abdominal pressure increase, hypoestrogenia, violations of the innervation and circulation of the pelvic floor, biochemical changes in the perineal tissues and genetic predisposition. Anterior vaginal wall prolapse is often accompanied by the urinary system functional disorders [11].

One of the most relevant and common genitourinary disorders is urinary incontinence (UI). This problem can occur in women as an independent disease or as a GP complication. According to the pathogenetic mechanisms UI is divided into 3 types: stressful, imperative and mixed. The prevalence of this pathology in the population is $30-50 \%$ and it negatively affects on the life quality of female population [11-13].

In 50-70\% of cases, vulvovaginal disorders are combined with cystourethral atrophy, that is explained by the presence of estrogen receptors in all pelvic organs, including ligaments and pelvic floor muscles. The estrogen deficiency leads to thinning of the squamous epithelium, reduction of lactobacilli number and vaginal $\mathrm{pH}$ increase which causes a vaginal biocenosis violation and supports a recurrent inflammatory reaction. Therefore, with an estrogen level decrease the following characteristic symptoms of atrophic changes appear. These symptoms do not pass over the time and lead to pelvic organs disorders [12-14].

Today, the main link in GS pathogenesis is considered to be undifferentiated connective tissue dysplasia (UCTD), which is manifested by a decrease in strength and a violation of the structure of the main components of connective tissue. The UCTD is manifested by the external phenotypic signs of connective tissue dysplasia, but are not included into one of the known syndroms of connective tissue pathology [2, 13, 15].

Today, the connective tissue dysplasia is understood as a violation of its development, which is characterized by defects in the main substance and fiber. Among the main causes of the UCTD are changes in the rate of synthesis and construction of collagen and elastin, the synthesis of immature collagen, violation of the structure of collagen and elastin fibers due to their insufficient lumbar stitching [2,13, 15]. Collagen acts as the main protein of the extracellular matrix and connective tissue. In humans, about 50 genes have been identified that encode various types of collagen and form 19 types of collagen fibers [2,5].

Thus, the main links in GS pathogenesis include: thinning and violation of the proliferation of the vaginal epithelium and urothelium, deterioration of blood supply, changes in the synthesis and exchange of collagen in the ligamentous apparatus of the pelvis, atrophy of myofibrils and violation of the anatomical location of the urinary system. All the above mentioned processes lead to the formation of atrophic changes in the urogenital tract epithelium [2].

Various conservative and surgical methods are used in GS treatment. The literature review indicates that the effectiveness of pharmacological agents in GS treatment is approximately $40-50 \%$, but it has a short-term effect in most cases and can be achieved mainly in mild forms of GS $[4,5,15,16,18,24]$. At the same time, side effects and 


\section{Н А ДОПОМОГУ Л ІКА Р - П АКТИКУ}

incompatibilities with a number of other drugs limit the possibility of their use [4, 15].

Currently, for the correction and treatment of GS, drugs containing estriol - a natural estrogen synthesized in the human body, and has a selective effect on the state of the urogenital diaphragm are widely used [12, 14, 22, 25-27]. However, given the increased risk of developing cancer, including breast cancer in this age group of women, the North American Menopausal Society and the International Society for the Study of Women's Sexual Health advises to limit the systemic use of estrogen medications that can act as an etiopathogenic treatment. At the same time, the society emphasizes the relative safety of local estrogen forms application in order to reduce and prevent GS symptoms. The use of estriol drugs helps to restore the physiology of the urogenital tract: vaginal epithelium, connective tissue elements of collagen and elastin [21].

The positive effect of estriol medications is realized by selectively acting on the urogenital tract, restoring normal microflora and physiological $\mathrm{pH}$ value of the vaginal contents, improving the proliferation of the mucous membrane of the external genitals, reducing the possibility of urogenital infections and preventing the urinary incontinence [2,32].

Physical therapy improves the contractile function of the pelvic floor muscles, eliminates a "gapping" effect of the perineum and restores an obturation function. However, physical therapy has almost no effect on the vaginal walls prolapse, whereas only the pelvic floor and lower third of the vagina are trained [5].

At the same time, none of these methods contributes to the complete disappearance of UI stress symptoms, and the frequency of relapses after the disease is high, which forces a woman to long-term monitoring and treatment, significantly impairing their life quality $[4,15]$. The search for alternative treatment methods led to the development and implementation of the new technology for GS correction which is based on the use of laser energy [19, 20, 21, 29, 34].

It should be noted that currently more and more information about the prospects of using minimally invasive laser technologies in urogynecology is being accumulated. But the information about its clinical effectiveness and safety in the treatment of UI stress in women are provided only in a few sources [4, 15, 19-21, 23]. Structural mechanisms of the therapeutic effect of laser radiation on the morpho-functional state of the vaginal walls after treatment with laser technologies remain insufficiently studied. Information about these mechanisms is provided only in selected publications [4, $33,35]$. This determines the prospect of further research in this area and the purpose of our research.

The objective: to determine and justify pathogenetically the effectiveness of CO2-laser application in the complex treatment of genitourinary syndrome in perimenopausal period patients.

\section{MATERIALS AND METHODS}

In order to achieve the purpose, a prospective examination of 130 women at the age of 45-55 years who were treated in the Gynecological Department No. 2 of the Kyiv City Maternity Hospital No. 3 and in the Medical center «Academy of Your Health» with manifestations of genitourinary syndrome, was conducted. All women were divided into two groups depending on the prescribed therapy. The main group consisted of 56 premenopausal age women with genitourinary syndrome, who were offered the therapy with the CO2-laser application. Proposed laser therapy involved 4 sessions performing at an interval of 3045 days with a laser power of $40 \mathrm{~W}$, exposure time of $1000 \mathrm{MS}$ and the distance between points-1000 microns.

The comparison group was formed by 74 women with genitourinary syndrome manifestations, who were intended only for therapy with local estriol application at the rate of one application of cream per day for a month, followed by further dosage reduction to one application twice a week for 7 months. The total duration of treatment for women in both groups was 8 months.

The criteria for inclusion in the research were the age of the women (between 45 and 55 years), GS clinical manifestations and the absence of acute extragenital pathology.

The criteria for exclusion from the research were epilepsy and mental disorders, acute pelvic inflammatory processes, sex transmitted diseases, vaginal wall prolapse of the 3rd grade and uterine prolapse, pregnancy and postpartum period, menstruation and cancer.

All patients before treatment had a set of examinations, including gynecological examination, cytological smear examination, ultrasound examination of the pelvic organs, pH-metry and Femoflor Screen testing. In the presence of GP, the severity of anterior and posterior vaginal walls prolapse was determined in the gynecological chair, and a cough test was performed.

To assess the functional status of the lower urinary tract, a comprehensive urodynamic examination (maximal intraurethral pressure, urethral closure pressure, functional length of the urethra) was performed. The efficacy of treatment was assessed before and after treatment based on the urodynamic data.

\section{RESULTS}

Both patients of the main and the comparison groups were comprehensive according to the place of residence, family and social status. That allowed to judge only the differences due to the method of stressful urinary incontinence treatment.

The average age of patients in the examined groups was $47.2 \pm 2.5$ years, but their structure was significantly dominated by women over 52 years old.

After the treatment according to the urodynamic examination, the maximum intraurethral pressure increased from $16.8 \pm 17.9$ to $26.7 \pm 21.2 \mathrm{~mm} \mathrm{Hg}$ in the main group $(\mathrm{p}<0.01)$. The urethral closure pressure increased from $15.3 \pm 13.2$ to $26.8 \pm 18.5 \mathrm{~mm} \mathrm{Hg}(\mathrm{p}<0.01)$. These changes were found upon examination of the functional length of the urethra, which increased from $2.0 \pm 0.3$ to $3.0 \pm 0.4 \mathrm{~cm}$, and thus reached normative values for healthy women. At the same time, the indicators in the pre-treatment and post-treatment comparison groups did not statistically differ. The results of the intra-urethral pressure profile are presented in table. 


\section{н А дОПОМОГУ Л І А РЮ-ПРАКТИКУ}

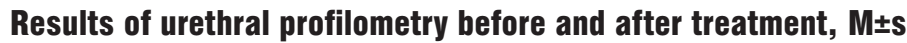

\begin{tabular}{|c|c|c|c|c|}
\hline \multirow{2}{*}{ Indicators } & \multicolumn{2}{|c|}{ Before treatment } & \multicolumn{2}{c|}{ After treatment } \\
\cline { 2 - 5 } & Main group & Comparison group & Main group & Comparison group \\
\hline Maximum intra-urethral pressure, $\mathrm{mm} \mathrm{Hg}$ & $16,8 \pm 17,9$ & $16,6 \pm 18,1$ & $26,7 \pm 21,2^{\star *}$ & $17,6 \pm 18,2^{\circ}$ \\
\hline Urethral occlusion pressure, $\mathrm{mmHg}$ & $15,3 \pm 13,2$ & $15,8 \pm 14,1$ & $26,8 \pm 18,5^{\star *}$ & $18,8 \pm 15,2^{\circ}$ \\
\hline Functional urethral length, $\mathrm{cm}$ & $2,0 \pm 0,3$ & $2,0 \pm 0,3$ & $3,0 \pm 0,4^{\star}$ & $2,5 \pm 0,4^{\circ}$ \\
\hline
\end{tabular}

Note: - * Statistically significant differences in outcomes before treatment, $p<0.05$ (t-Student's test);

- ** statistically highly significant difference from the pre-treatment results, $p<0.01$ (t-test);

$-{ }^{\circ}$ statistically insignificant differences in comparison to the pre-treatment results, $p>0.05$ (t-test).

\section{CONCLUSIONS}

The inclusion of CO2-laser therapy to the complex treatment of genitourinary syndrome can significantly reduce the manifestations of genitourinary disorders, which is confirmed by urodynamic examinations before and after treatment.

The positive therapeutic result of the $\mathrm{CO} 2$-laser, from our point of view, occurs due to the effect on the ethiopathogenetic mechanisms of the syndrome complex.

Thus, the results of our study show that the MonaLisaTouch laser fractionated ablation of the vaginal epithelium and vulva is highly effective compared to local hormonal therapy and can be recommended as a monotherapy for pelvic floor dysfunction.

\section{Information about the authors}

Beniuk Vasyl O. - Department of Obstetrics and Gynaecology № 3 Bogomolets National Medical University, 03148, Kyiv, Kuchera str., 7.E-mail: benyuk@i.ua

ORCID ID 0000-0002-5984-3307

Goncharenko Vadym M. - Department of Obstetrics and Gynaecology № 3 Bogomolets National Medical University, 03148, Kyiv, Kuchera str., 7.

ORCID ID 0000-0002-8317-3737

Puchko Maryna S. - Department of Obstetrics and Gynaecology № 3 Bogomolets National Medical University, 03148, Kyiv, Kuchera str., 7.E-mail:puchkomarri@gmail.com

ORCID ID 0000-0002-2936-7741

Momot Alona A. - Department of Obstetrics and Gynaecology № 3 Bogomolets National Medical University, 03148, Kyiv, Kuchera str., 7.E-mail:alionamomot@ukr.net

ORCID ID 0000-0001-8406-7816

Polovynka Vladyslav O. - Department of Clinical Pharmacology and Clinical Pharmacy, Bogomolets National Medical University,01601, Kyiv,13 T. Shevchenko Blvd.

ORCID ID 0000-0002-5893-5402

Kovaliuk Tetiana V. - Department of Obstetrics and Gynaecology № 3 Bogomolets National Medical University, 03148, Kyiv, Kuchera str., 7.E-mail:tatyanah7@meta.ua

ORCID: 0000-0001-9339-881X

\section{Відомості про авторів}

Бенюк Василь Олексійович - Кафедра акушерства і гінекології № 3 Національного медичного університету імені О.О. Богомольця, 03148, м. Київ, вул. В. Кучера, 7. E-mail: benyuk@i.ua

ORCID ID 0000-0002-5984-3307

Гончаренко Вадим Миколайович - Кафедра акушерства і гінекології № 3 Національного медичного університету імені О.О. Богомольця, 03148, м. Київ, вул. В. Кучера, 7

ORCID ID 0000-0002-8317-3737

Пучко Марина Сергіївна - Кафедра акушерства і гінекології № 3 Національного медичного університету імені О.О. Богомольця, 03148, м. Київ, вул. В. Кучера, 7. E-mail:puchkomarri@gmail.com

ORCID ID 0000-0002-2936-7741

Момот Альона Анатоліївна - Кафедра акушерства і гінекології № 3 Національного медичного університету імені О.О. Богомольця, 03148, м. Київ, вул. В. Кучера, 7. E-mail: alionamomot@ukr.net

ORCID ID 0000-0001-8406-7816

Половинка Владислав Олександрович - Кафедра клінічної фармакології та клінічної фармації Національного медичного університету імені О. О. Богомольця, 01601, м. Київ, бул. Т. Шевченка, 13

ORCID ID 0000-0002-5893-5402

Ковалюк Тетяна Володимирівна - Кафедра акушерства і гінекології № 3 Національного медичного університету імені О.О. Богомольця, 03148, м. Київ, вул. В. Кучера, 7

ORCID: 0000-0001-9339-881X 


\section{н А до ПО Могу Л І А Р Ю П РАКТ ИКУ}

\section{Сведения об авторах}

Бенюк Василий Алексеевич - Кафедра акушерства и гинекологии № 3 Национального медицинского университета имени А.А. Богомольца, 03148, г. Киев, ул. В. Кучера, 7. E-mail: benyuk@i.ua

ORCID ID 0000-0002-5984-3307

Гончаренко Вадим Николаевич - Кафедра акушерства и гинекологии № 3 Национального медицинского университета имени А.А. Богомольца, 03148, г. Киев, ул. В. Кучера, 7

ORCID ID 0000-0002-8317-3737

Пучко Марина Сергеевна - Кафедра акушерства и гинекологии № 3 Национального медицинского университета имени А.А. Богомольца, 03148, г. Киев, ул. В. Кучера, 7. E-mail:puchkomarri@gmail.com

ORCID ID 0000-0002-2936-7741

Момот Алёна Анатольевна - Кафедра акушерства и гинекологии № 3 Национального медицинского университета имени А.А. Богомольца, 03148, г. Киев, ул. В. Кучера, 7 E-mail: alionamomot@ukr.net

ORCID ID 0000-0001-8406-7816

Половинка Владислав Александрович - Кафедра клинической фармакологии и клинической фармации Национального медицинского университета имени А.А. Богомольца, 01601, г. Киев, бул. Т. Шевченко, 13

ORCID ID 0000-0002-5893-5402

Ковалюк Татьяна Владимировна - Кафедра акушерства и гинекологии № 3 Национального медицинского университета имени А.А. Богомольца, 03148, г. Киев, ул. В. Кучера, 7

ORCID: 0000-0001-9339-881X

\section{REFERENCES}

1. Apolihina I.A., Gorbunova E.A. Clinical and morphological aspects of vulvovaginal atrophy. Medicinskij sovet. 2014; 9: 110-7. 2. Arsent'ev V.G., Sereda Ju.V., Thonov V.V. and others. Connective tissue dysplasia is the constitutional basis of multiple organ disorders in children and adolescents. Pediatrija. Zhurnal im. G.N. Speranskogo. 2011; 90 (2): $54-7$

3. Balan V.E., Kovaleva LA. Comprehensive treatment of urogenital atrophy and recurrent urinary tract infections in postmenopause. Jeffektivnaja farmakoterapija. Akusherstvo i ginekologija. 2013; 2 (18): 10-4.

4. Bezmenko A.A., Shmidt A.A., Koval' A.A., Karpishhenko Zh.M. Conservative methods of treatment of urinary incontinence under stress in women. Vestnik Rossijskoj Voenno-medicinnskoj akademii. 2014; 45 (1): 227-32.

5. Gvozd'ov M.Ju., Tupikina N.V., Kasjan G.R., Pushkar D.Ju. Pelvic organ prolapse in the clinical practice of a urologist. Metodychni rekomendacii' . 2016; 2: 22-38. 6. Glazunova A.V., Jureneva S.V. The prevalence of vulvovaginal atrophy and its impact on the quality of life of women. Questions of terminology and safety of local hormone therapy. Akusherstvo i ginekologija. 2014; 11: 29-33.

7. Gorbunova E.A., Apolihina I.A. Atrophic zestoretic as one of the faces genitourinary syndrome. Effektivnaja farmakoterapija. Akusherstvo i ginekologija. 2015; 4 (36): 31-6.

8. Dobrohotova Ju.Je., Ibragimova D.M., Mandrykina Zh.A., Serova L.G. Microbiocenosis of the female genital tract. M.: GEOTAR-Media; 2015. $80 \mathrm{p}$.

9. Il'ina I.Ju., Dobrohotova Ju.Je., Venediktova M.G., Utina M.S. i soavt. Effective correction of genitourinary menopausal syndrome by laser fractional ablation. RMZh. Mat' i ditja. 2018; 5 (1): 4-8.
10. Il'ina I.Ju., Dobrohotova Ju.Je. Non-surgical methods of correction of genital prolapse and urination disorders. Ginekologija. 2016; 18 (2): 28-31.

11. Il'ina I.Ju., Dobrohotova Ju.Je. Features of urination in gynecological patients. Medicinskij sovet. 2014; 19: 21-25.

12. Kuznecova I.V., Chushkov Ju.V., Ishhenko A.I. The role of local use of estriol in optimizing the outcomes of surgical treatment of genital prolapse in peri - and postmenopausal patients. Akusherstvo i ginekologija. 2015; 19: 2-6.

13. Kulakov V.I., Manuhin I.B., Savel'eva G.M. National guide to gynecology. M.: GEOTAR-Media. 2011: 1120

14. Leonova Z.A., Forensov V.V. Synthesis and functions of female sex hormones. Sibirskij medicinskij zhurnal. 2013; 117 (2): 10-12.

15. Nejmark A.I., Razdorskaja M.V. Urinary incontinence in women. M.: GEOTAR-Media. 2013: 123.

16. Tumilovich L.G., Gevorkjan M.A. Directory of gynecologistendocrinologist. M.: Prakticheskaja medicina. 2014: 208.

17. Shestakova I.G. Vaginal atrophy in the practice of an obstetrician-gynecologist. Ginekologija. 2014; 6: 7-11.

18. Arroyo C. Fractional $\mathrm{CO} 2$ laser treatment for vulvovaginal atrophy symptoms and vaginal rejuvenation in perimenopausal women. Int J Womens Health. 2017: 28 (9): 591-5. DOI: 10.2147/JWH.S136857. 19. Athanasiou S., Pitsouni E., Falagas M.E. et al. CO2 -laser for the genitourinary syndrome of menopause. How many laser sessions? // Maturitas. 2017; 104: 24 -28. DOl: 10.1016/J. maturitas.2017.07.00 20. Behnia-Willison F., Sarraf S., Miller J. et al. Safety and longterm efficacy of fractional CO (2) laser treatment in women suffering from genitourinary syndrome of menopause. Eur J Obstet Gynecol Reprod
Biol. 2017; 213: 39-44. DOI: 10.1016/J. ejogrb.2017.03.036.

21. Consensus Recommendations. Management of genitourinary syndrome of menopause in women with high risk for breast cancer: consensus recommendations from The North American Monopause Society and the International Society for the Study of Women's Sexual Care. 2018; 25 (6): 1-13. DOI: 10.1097/ GME.0000000000001121

22. Elisabeth A. Erekson, Sallis O. Yip, Terri $\mathrm{S}$. Wedderburn et al. The VSQ: a questionnaire to measure vulvovaginal symptoms in postmenopausal women. Menopause. 2013; 20 (9): 973-9. DOI: 10.1097/ GME.0b013e318282600b

23. Fistonić N, Fistonić I, Lukanovič A, Findri Guštek Š, Sorta Bilajac Turina I, Franić D. First assessment of shortterm efficacy of Er: YAG laser treatment on stress urinary incontinence in women: prospective cohort study. Climacteric. 2015; 18 (1): 37-42. DOl: 10.3109/13697137.2015.1071126

24. Gambacciani M., Palacios S. Laser therapy for the restoration of vaginal function. Maturitas. 2017; 99: 10 - 15. DOl: 10.1016/

25. Gaspar A, Addamo G, Brandi H. Vaginal Fractional CO2 Laser: A Minimally Invasive Option for Vaginal Rejuvenation. Am.J Cosmetic Surg. 2011; 28 (3): 156-62. DOI:10.1177/074880681102800309 26. Management of symptomatic vulvovaginal atrophy: 2013 position statement of The American Menopause Society. Menopause. 2013; 20 (9): 888-902. DOI: 10.1097/ GME.0b013e3182a122c2

27. Moreira A.C, Silva A.M., Santos M.S., Sardao V.A. Phytoestrogens as alternative hormone replacement therapy in menopause: What is real, what is unknown. J. Steroid BiochemMol.Biol. 2014; 21:61-71. DOl: 10.1016/J. jsbmb.2014.01.016.

28. Nappi R.E., Palacios S. Impact of vulvovaginal atrophy on sexual health and quality of life at postmenopause. Climacteric. 2014; 17 (1): 3-9. DOI: 10.3109/13697137.2013.871696 29. Nede O. Williams, Maryam B. Lustberg.. Time for Action: Managing of Genitourinary Syndrome of Menopaues. Journal of Oncology Practice. 2019; 15 (7): 371. DOI 10.1200/JOP. 19.00350

30. Ogrinc U.B., Senear S., Lenasi H. Novel minimally invasive laser treatment of urinary incontinence in women. Lasers Surg. Med. 2015; 47 (9): 689-97. DOI: 10.1002/ Ism.22416

31. Pagano I., GieriS., Nocera F. etal. Evaluation of the CO2 Laser Therapy on VulvoVaginal Atrophy (WA) in Oncological Patients: Preliminary Results. J Cancer Ther. 2017; 8 (5): 452-63. DOl: 10.4236/jct.2017.85039 32. Perino A., Calligaro A., Forlani F. et al. Vulvo-vaginal atrophy: a new treatment modality using thermo-ablative fractional $\mathrm{CO} 2$ laser. Maturitas. 2015; 80 (3): 296-301. DOl: 10.1016/J. maturitas.2014.12.006

33. Portman D.J., Gass M.L. Vulvovaginal Atrophy Terminology Consensus Conference Panel. Genitourinary syndrome of menopause: new terminology for vulvovaginal atrophy from the International Society for the Study of Women's Sexual Health and the North American Menopause Society. Maturitas. 2014; 79 (3): 349-54. DOl: 10.1016/j. maturitas. 2014.07.013

34. Rossella E. Nappi, E. Martini, L. Cucinella, S. Martella et al. Addressing Vulvovaginal Atrophy (WA)/Genitourinary Syndrome of Menopause (GSM) for Health Aging in Women. Frontiers in Endocrinology. 2019; 10: 1-11. DOl 10.3389/ fendo.2019.00561 35. Stefano S., Stavros A., Massimo C. The use of pulsed $\mathrm{CO} 2$ lasers for the treatment of vulvovaginal atrophy. Curr Opin Obstet Gynecol. 2015; 27 (6): 504-8. DOI: 10.1097/GCO.0000000000000230 